\title{
Sowing Dates: A Major Factor on the Incidence of Major Insect Pests and Yield of Mungbean
}

\author{
M. Altaf Hossain ${ }^{*}$, M. Z. H. Prodhan ${ }^{2}$ \& M. A. SARKER ${ }^{3}$ \\ ${ }^{1}$ Regional Agricultural Research Station, Bangladesh Agricultural Research Institute, Ishurdi-6620, \\ Pabna, Bangladesh \\ ${ }^{2}$ Regional Agricultural Research Station, Bangladesh Agricultural Research Institute, Ishurdi-6620, \\ Pabna, Bangladesh \\ ${ }^{3}$ Bangladesh Agricultural Research Institute, Joydebpur, Gazipur-1701, Bangladesh
}

\begin{abstract}
An experiment was conducted at Pulses Research Center, Ishurdi, Pabna, Bangladesh during kharif-I to find out the insect pests attacking mungbean crop sowing at different dates to determine the optimum date(s) of sowing. It is seen that the incidence and population fluctuation of various insect pests was very much dependent on the prevailed climatic conditions of the cropping season. The early (February 14 to March 06) and late sown (mid April to onward) crops received higher pest infestation than mid sown (March 13 to April 10) crops. The highest yield (1548 kg/ha) was obtained from March 27 sowing crop. The second highest yield (1279 kg/ha) was obtained from March 13 sowing which was statistically identical to March 20, April 03 and April 10 sowings crop. Again, the delayed sowings after mid April to onward provide yield of $717 \mathrm{~kg} / \mathrm{ha}$ to $178 \mathrm{~kg} / \mathrm{ha}$ which were very poor. Hence, for ensuring higher yield and less insect pest's infestation, mungbean should be sown within the period of March 13 to April 10 and the best date of sowing should be March 27.
\end{abstract}

Key words: Sowing dates, pest infestation and yield of mungbean.

\section{INTRODUCTION}

Mungbean (Vigna radiata L) is one of the important pulse crop in Bangladesh. Due to its short lifespan gradually farmers are becoming more interested to cultivate this valuable crop after harvesting of rabi crops (kharif-I season). Several insect pests have been reported to infest mungbean damaging the crops during seedlings, leaves, stems, flowers, buds and pods causing considerable losses (Litsinger et al.1988, Sehgal and Ujagir 1988, Rahman and Miah 1988, Karim and Rahman 1991, Husain 1993). More than twelve species of insect pests were found to infest mungbean in Bangladesh (Anonymous 1998), among them stemfly (Lal 1985, Rahman 1987), jassid (Baldev et al. 1988), aphid and whitefly (Rahman et al. 1981), thrips (Rahman et al. 1981, Hossain et al. 2004), hairy caterpillar (Rahman et al. 1981) and pod borers (Rahman et al. 1981, Hossain et al. 2004) are important..

Pest appearance, population fluctuation, infestation rate and crop yield are very much dependent on sowing time. Most of the farmer's usually sown mungbean just after harvesting the

* Corresponding author: SSO, RARS, Bangladesh Agricultural Research Institute, Ishurdi-6620, Pabna, Bangladesh

(C) 2009 School of Agriculture and Rural Development, Bangladesh Open University, All rights reserved. 


\section{Altaf Hossain et al.}

rabi crops without considering optimum sowing dates. If they get free land early then they sown early or if it is late they sown late. As a result crops growth affected by unfavourable prevailing climatic condition and also crop received higher pest infestation and accordingly yields become reduced. Information regarding insect pest's appearance, infestation and its severity of damage in relation to sowing time is not available in Bangladesh specially for mungbean crops Therefore, the present study was undertaken to investigate the insect pests attacking mungbean, their severity of damage and its effect on grain yield in relation to variation of sowing dates.

\section{MATERIALS AND MethodS}

The experiments were conducted at Pulses Research Center, Ishurdi, Pabna, Bangladesh during kharif-I, 2008. Twelve sowing dates at 7 days intervals starting from February 14 to May 01 were considered as different treatments to find out the pest incidence, their damage severity and its effect on grain yield. The experiments were laid out in randomized complete block design with three replications. The treatments were randomly allotted in each block. The unit plot size was $3 \mathrm{~m} \times 4 \mathrm{~m}$ with a distance of $100 \mathrm{~cm}$ between the plots and $150 \mathrm{~cm}$ between the replications. The seeds of BARI-mung 6 were sown in rows with the spacing of $30 \mathrm{~cm}$. NPK fertilizers @ 20-40-20 kg/ha in the form of urea, triple super phosphate and muriate of potash were applied during final land preparation in each sowing.

The mungbean plants of different sowing dates were closely examined at regular interval commencing from germination till harvest. Data on the first appearance of major insect pests in the field were recorded.

Percentage of leaf area damaged by flea beetle was determined by eye estimation and percentage of aphid infested plants was recorded during pod developing stage of each sowing date.

Thrips population (thrips/flower/day) was assessed from 20 opened flowers randomly collected from two rows from each plot avoiding border and central rows. The collected flowers were immediately bagged in a polybag containing ethyl acetate soaked cotton balls to kill the thrips for easy counting of their population. Central four rows were kept undisturbed for recording yield data.

At maturity ten randomly selected plants were uprooted from central rows of each plot and brought in the laboratory for measuring stem length. Stems of each plant was dissected for measuring the length of the tunnel. Percentage of stemfly infestation was determined on stem tunneling.

For recording percentage of pod borer damage data, all the pods were collected from those 10 randomly selected plants of each plot and examined. The damaged (bored) and total pod numbers were counted and per cent pod damage was determined.

The crop of central four rows of each plot comprising $8 m^{2}(2 m \times 4 m)$ area was harvested. The grain yield obtained from each plot was converted for yield per hectare.

The experimental data were analyzed by MSTAT-C software. The per cent data were transformed by square root or arc sine transformation for statistical analysis. Mean comparisons for treatment parameters were compared using Duncan's Multiple Range Test (Steel and Torrie, 1960) at $5 \%$ level of significance.

\section{Results AND Discussion}

\section{Effect of sowing dates on the incidence of stemfly}

Stemfly infestation varied (50 to 100\%) significantly depending on the dates of sowing (Table 1). The highest stemfly infestation (100.00\% plant infested) was recorded in March 20 and April 10 sowing crops which was statistically identical to February 28 to onward sowings upto May 01 
(except March 13). The lowest infestation (50.00\% plant infested) was observed in February 14 sowing crop followed by February 21 (70.00\% plant infested).

Table 1. Effects of sowing dates on the incidence of stemfly, flea beetle and aphid in mungbean during kharif-I 2008 at Ishurdi, Pabna, Bangladesh

\begin{tabular}{lllll}
\hline $\begin{array}{c}\text { Treatments } \\
\text { (Sowing dates) }\end{array}$ & $\begin{array}{c}\text { Stemfly infested } \\
\text { plant (\%) }\end{array}$ & $\begin{array}{c}\text { Stem tunneling } \\
\text { /plant (\%) }\end{array}$ & $\begin{array}{c}\text { Leaf area damaged } \\
\text { by flea beetle (\%) }\end{array}$ & $\begin{array}{c}\text { Aphid infested } \\
\text { plant (\%) }\end{array}$ \\
\hline $\mathrm{T}_{1}=14.02 .08$ & $50.00(3.91)^{\star} \mathrm{d}$ & $13.86(3.71)^{\star \star} \mathrm{ab}$ & $2.33(1.52)^{\star \star} \mathrm{e}$ & $41.88(3.58)^{\star} \mathrm{b}$ \\
$\mathrm{T}_{2}=21.02 .08$ & $70.00(4.61) \mathrm{c}$ & $12.83(3.54) \mathrm{a}-\mathrm{c}$ & $3.33(1.82) \mathrm{e}$ & $57.37(4.19) \mathrm{a}$ \\
$\mathrm{T}_{3}=28.02 .08$ & $90.00(5.25) \mathrm{ab}$ & $15.37(3.92) \mathrm{a}$ & $3.67(1.91) \mathrm{e}$ & $38.76(3.44) \mathrm{b}$ \\
$\mathrm{T}_{4}=06.03 .08$ & $90.00(5.25) \mathrm{ab}$ & $12.18(3.48) \mathrm{a}-\mathrm{c}$ & $4.00(1.99) \mathrm{e}$ & $25.77(2.80) \mathrm{cd}$ \\
$\mathrm{T}_{5}=13.03 .08$ & $80.00(4.94) \mathrm{bc}$ & $9.87(3.13) \mathrm{cd}$ & $4.00(1.99) \mathrm{e}$ & $28.40(2.94) \mathrm{c}$ \\
$\mathrm{T}_{6}=20.03 .08$ & $100.00(5.54) \mathrm{a}$ & $15.09(3.88) \mathrm{a}$ & $3.67(1.88) \mathrm{e}$ & $12.39(1.94) \mathrm{f}$ \\
$\mathrm{T}_{7}=27.03 .08$ & $96.67(5.44) \mathrm{ab}$ & $13.82(3.72) \mathrm{ab}$ & $2.67(1.58) \mathrm{e}$ & $20.27(2.43) \mathrm{de}$ \\
$\mathrm{T}_{8}=03.04 .08$ & $96.67(5.44) \mathrm{ab}$ & $12.43(3.53) \mathrm{a}-\mathrm{c}$ & $14.33(3.76) \mathrm{c}$ & $8.57(1.61) \mathrm{f}$ \\
$\mathrm{T}_{9}=10.04 .08$ & $100.00(5.54) \mathrm{a}$ & $10.87(3.30) \mathrm{b}-\mathrm{d}$ & $6.67(2.57) \mathrm{d}$ & $14.04(2.07) \mathrm{ef}$ \\
$\mathrm{T}_{10}=17.04 .08$ & $90.00(5.25) \mathrm{ab}$ & $8.43(2.89) \mathrm{d}$ & $27.33(5.23) \mathrm{ab}$ & $13.31(2.01) \mathrm{ef}$ \\
$\mathrm{T}_{11}=24.04 .08$ & $86.66(5.15) \mathrm{ab}$ & $9.24(3.04) \mathrm{cd}$ & $22.33(4.72) \mathrm{b}$ & $11.41(1.86) \mathrm{f}$ \\
$\mathrm{T}_{12}=01.05 .08$ & $83.33(5.14) \mathrm{abc}$ & $10.46(3.23) \mathrm{b}-\mathrm{d}$ & $32.33(5.69) \mathrm{a}$ & $11.56(1.87) \mathrm{f}$ \\
\hline
\end{tabular}

Means in a column having same letter(s) did not differ significantly at $5 \%$ by DMRT

${ }^{*}$ Figures in the parentheses are transformed arcsine values

${ }^{*}$ Figures in the parentheses are transformed square root values

Percentage of stem tunneling per plant also varied (8.43\% to $15.37 \%)$ significantly depending on the dates of sowing. The highest percentage of stem tunneling (15.37\%) was found in February 28 which was statistically identical to other sowings in February and March (except March 13 and April 03). Of the 12 sowing dates, April 17 had the lowest percentage of stem tunneling (8.43\%) that was statistically identical to March 13, April 10, April 24 and May 01.

Therefore, it is seen that stemfly infestation was lower in February sowings than those of March and April sowings. Again, per cent stem tunneling per plant was lower in April sowings crop than those of February and March sowings.

\section{Effect of sowing dates on the incidence of flea beetle}

Sowing dates influenced flea beetle infestation significantly. The lowest percentage of leaf area damaged by flea beetle (2.33\%) was observed in first sowing i.e., February 14 which was statistically identical to all the sowing dates of February and March. The highest percentage of leaf area damage by flea beetle (32.33\%) was observed in last sowing i.e., May 01 followed by April sowings crop. It is seen that flea beetle infestation increased with delaying of sowing dates. This might be due to occurrence of higher rainfall in delayed sowing crops which favoured population increase of flea beetle causing higher leaf infestation.

\section{Effect of sowing dates on the incidence of aphid}

Sowing dates significantly affected aphid infestation in mungbean. Percentage of plant infestation by aphid in different dates of sowing ranged from $8.57 \%$ to $57.37 \%$ (Table 1 ). The highest percentage (57.37\%) of plant infestation was observed in February 21 sowing crops followed by February 14 and February 28. Aphid infestation was lower in those crops sown in March than those of February sowings. The lowest percentage (8.57\%) of plant infestation was observed in April 03 sowing crop which was statistically identical to March 20, April 10, April 17, April 24 and May 01. Generally, it is seen that aphid infestation was higher in February sowings crops followed by March, April and May sowings. This might be due to lower temperature in early sowings crops which favoured population increase to higher infestation. . Hossain et al. $(2000,2006)$ reported that aphid infestation in lentil varied significantly depending on sowing time. 


\section{Altaf Hossain et al.}

\section{Effect of sowing dates on thrips population}

Thrips population in mungbean flower differed significantly depending on sowing dates, ranging from 1.20 thrips/flower/day to 3.98 thrips/flower/day (Table 2). The highest thrips population (3.98 thrips/flower/day) was observed in February 14 sowing crops followed by February 21 and February 28 sowings. The lowest thrips population (1.20 thrips/flower/day) was observed in March 06 sowing crops which was identical to all the sowings of March. In April sowings crops, thrips population increased than those of March sowings crop. Thrips population was statistically identical in all the sowing dates of April. It is seen that thrips population was higher in early (February14 to March 06) and late (April 13 and onward) sowing crops than mid sowings (March 13 to April 10).

Table 2. Effects of sowing dates on the incidence of thrips and pod borer in mungbean during kharif-I 2008 at Ishurdi, Pabna, Bangladesh

\begin{tabular}{ccc}
\hline Treatments (Sowing dates) & No. of thrips /flower /day & Pod damage by pod borer (\%) \\
\hline $\mathrm{T}_{1}=14.02 .08$ & $3.98 \mathrm{a}$ & $10.06(1.74)^{\star} \mathrm{g}$ \\
$\mathrm{T}_{2}=21.02 .08$ & $3.93 \mathrm{a}$ & $11.46(1.86) \mathrm{fg}$ \\
$\mathrm{T}_{3}=28.02 .08$ & $3.01 \mathrm{bc}$ & $22.21(2.48) \mathrm{C}-\mathrm{e}$ \\
$\mathrm{T}_{4}=06.03 .08$ & $1.20 \mathrm{~d}$ & $15.83(2.20) \mathrm{ef}$ \\
$\mathrm{T}_{5}=13.03 .08$ & $1.52 \mathrm{~d}$ & $14.20(2.07) \mathrm{e}-\mathrm{g}$ \\
$\mathrm{T}_{6}=20.03 .08$ & $1.46 \mathrm{~d}$ & $17.43(2.30) \mathrm{de}$ \\
$\mathrm{T}_{7}=27.03 .08$ & $1.79 \mathrm{~d}$ & $9.25(1.68) \mathrm{g}$ \\
$\mathrm{T}_{8}=03.04 .08$ & $2.57 \mathrm{C}$ & $26.00(2.83) \mathrm{bc}$ \\
$\mathrm{T}_{9}=10.04 .08$ & $2.74 \mathrm{C}$ & $23.38(2.67) \mathrm{cd}$ \\
$\mathrm{T}_{10}=17.04 .08$ & $2.70 \mathrm{C}$ & $33.84(3.21) \mathrm{ab}$ \\
$\mathrm{T}_{11}=24.04 .08$ & $2.44 \mathrm{C}$ & $36.33(3.33) \mathrm{a}$ \\
$\mathrm{T}_{12}=01.05 .08$ & $3.41 \mathrm{ab}$ & $38.54(3.43) \mathrm{a}$ \\
\hline
\end{tabular}

Means in a column having same letter(s) did not differ significantly at $5 \%$ by DMRT

*Figures in the parentheses are transformed arcsine values

\section{Effect of sowing dates on the incidence of pod borer}

Pod damaged by pod borer varied significantly due to different sowing dates. The lowest pod damage (9.25\%) was observed in March 27 sowing crops which was statistically identical to February 14, February 21 and March 13 sowings crop. The highest pod damage (38.54\%) was observed in May 01 sowing crops which was statistically identical to April 17 and April 24 sowings crops. It is seen that in February and March sowings crop pod borer damage was comparatively low than that of April and May sowings crops. This might be due to higher rainfall in April-May sowings favouring pod borer population increase caused higher pod infestation. Jayaramiah and Babu (1990) reported rainfall as the influencing factor of pod borer moth emergence as well as higher pod borer infestation.

\section{Other insect pests}

In the present experiment, the presence of other insect pests like, whitefly, jassid, hairy caterpillar and semilooper were seen very scattered and difficult to study.

\section{Effect of sowing dates on yield (kg/ha)}

Grain yield of mungbean varied to the variation of sowing dates and insect pest infestation (Fig. 1). It was observed that both the early (February14 to March 06) and late sown (April 13 and onward) crops received higher insect pest's infestation and provided lower yield. But mid sown (March 13 to April 10) crops received less insect pest's infestation and produced higher yield. In early sown crops, cool temperature stunted the plant growth with higher thrips and aphid infestation. However, in mid sown crops optimum temperature favoured the optimum growth with higher pod setting and less insect pest's infestation. In case of late sowings, higher temperature and rainfall affected the plant growth with less pod setting and higher flea beetle and pod borer infestation which resulted poor yield. 


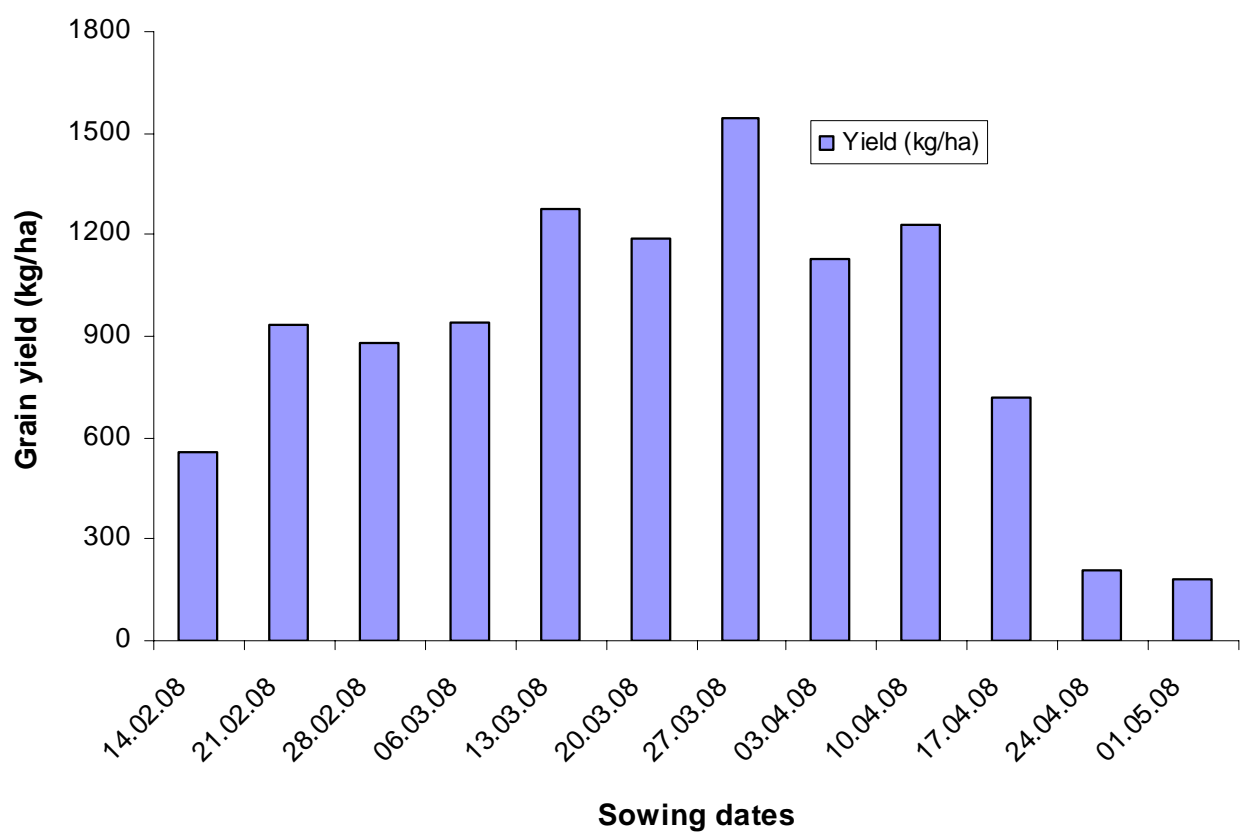

Fig. 1 Grain yield (kg/ha) of mungbean in different sowing dates during kharif 12008 at Ishurdi, Pabna, Bangladesh

Relationship between flower thrips population and yield (Fig. 2) gave a negative correlation ( $y=$ $\left.228.61 x+1485.2 ; R^{2}=0.2596\right)$, indicating the increase of thrips population in flower causes a progressive loss in yield. For each thrips/flower/day increase, there was a decrease of yield by $228.61 \%$. The correlation coefficient $(r)$ was 0.509 and the contribution of regression indicated that $25.96 \%$ yield loss occurred by flower thrips.

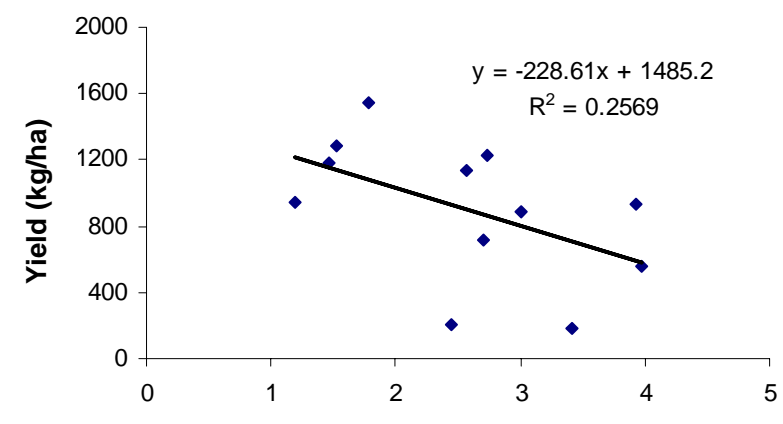

No. of thrips/flower/day

Fig. 2. Relationship between thrips population and yield in mungbean during kharif-I 2008 


\section{Altaf Hossain et al.}

\section{Relationship between pod borer damage and yield}

The relationship between pod borer damage and yield at different sowing dates indicated a negative correlation $\left(y=-23.565 x+1420.9 ; R^{2}=0.3627\right)$. For every $1 \%$ increase of pod borer damage, there was a decrease of yield by $23.56 \%$. The correlation coefficient $(r)$ was 0.602 and the contribution of regression indicated that $36.27 \%$ yield might be decreased by pod borer damage (Fig. 3).

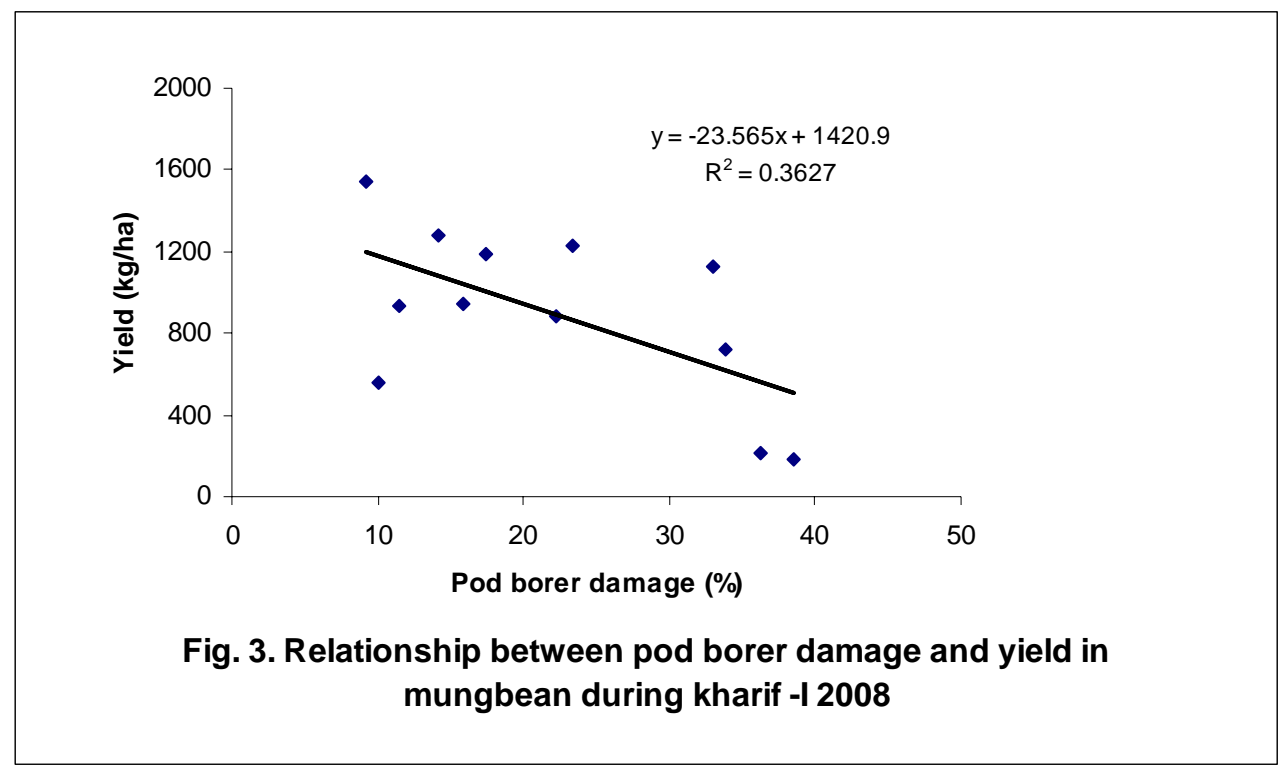

\section{CONCLUSIONS}

It is concluded that the incidence and population fluctuation of insect pests of mungbean was very much dependent on the prevailing climatic conditions of the cropping season. Both the early and late sown crops received higher insect pest infestation than mid sown crops. Hence, for ensuring higher yield with less insect pest's infestation, mungbean should be sown within the period of March 13 to April 10 and the best date of sowing would be March 27.

\section{LiterATURE CiTED}

Anonymous. 1998. Effect of sowing date and insecticides against stemfly and pod borer of blackgram. Annual Report 1997/1998. Bangladesh Agricultural Research Institute (BARI). Joydebpur, Gazipur, Bangladesh . pp. 104-105.

Baldev, B., Ramanujam S. and Jain, H.K. 1988. Pulse crops. Oxford IBH Publishing Co. Pvt .Ltd. New Delhi. pp. 229-258.

Hossain, M.A., Islam, K.M.S. and Mondal, A.T.M.A.I. 2000. Effect of sowing date on lentil aphid, Aphis craccivora Koch infestation and yield contributing characters of lentil (Lens culinaris Medik). J. Bio-sci. 8, 115-117.

Hossain, M.A., Ferdous, J., Sarkar, M.A. and Rahman, M.A. 2004. Insecticidal management of thrips and pod borer in mungbean. Bangladesh J. Agril. Res. 29(3), 347-356.

Hossain, M.A., Ferdous, J. and M.M.R. Salim. 2006. Relative abundance and yield loss assessment of lentil aphid, Aphis craccivora Koch in relation to different sowing dates. J. Agric. Rural Dev. 4(1\&2), 101-106. 
Husain, M. 1993. "Anistakari Kit -patanga Daman (in Bengali )". Bangla Academy. Dhala, 220p.

Jayaramiah, M. and Babu, J.C.S. 1990. Present status of Helicoverpa armigera in pulses and strategies for its management in Karnataka. Proceedings of the First National Workshop on Helicoverpa management. Directorate of Pulse Research, Kanpur, India, 30-31 ${ }^{\text {st }}$ August, 1990.

Karim, M.A. and Rahman, M.M.1991. Status of insect and vertebrate pest management research on pulses. pp. 135-138. In: proceedings of the second National Workshop on Advances in pulses Research in Bangladesh, 6-8 June 1989, Joydebpur, Bangladesh.

Lal, S.S. 1985. A review of insect pests of mungbean and their control in India. Trop. Pest Management, 31(2), 105-114.

Litsinger, J .A., Barrion, A.T., Bangdog, J.P., dela Cruz, C .G., Canapi, B.L. and Apostol, R.F. 1988. Food web, yield loss and chemical control of insect pests of wetland rice -based mungbean in the Philippines. Mungbean: Proceedings of the second International Symposium. Asian Vegetable Research and Development Center, Shanhua, Taiwan.

Rahman, M.M., Mannan, M.A. and Islam, M.A.1981. Pest survey of major summer and winter pulses in Bangladesh, In the Proceedings of the National Workshop on pulses.(eds.) A.K. Kaul. pp.265-273.

Rahman, M.M. 1987. Evaluation of Sumithion as a component of an integrated pest management program to control insect pest of mungbean. Abstract of the Bangladesh Science Conference12, Bangladesh Association for Advancement of Science. Section 1, 38-39.

Rahman, M.M. and Miah, A.A. 1988. Mungben in Bangladesh- Problem and Prospects. In: Shanmugasundaram, S(ed.) Mungbean: Proceedings of the second International Symposium on Mungbean. 16-20 November 1987. Bankok, Thailand. AVRDC, Shanhua, Tainan ,Taiwan (ROC). 570p.

Sehgal.V.K.and Ujagir, R. 1988. Insect and pest management of mungbean in India. Mungbean: Proceedings of the Second International Symposium. Asian Vegetable Research and Development center, Shanhua ,Taiwan .

Steel, R.G.D. and J.H. Torrie. 1960. Principles and Procedures of Statistics, pp. 107-109. McGrawHill Book. Co. Inc., New York. 